\title{
Spatial differences and chronology of metasomatism in depleted mantle xenoliths beneath Kimberley, South Africa
}

\author{
Tatjana Rehfeldt ${ }^{1}$, Dorrit E. Jacob ${ }^{1}$, Stephen F. Foley ${ }^{1}$ and Richard W. Carlson ${ }^{2}$ \\ ${ }^{I}$ Mainz University, Department of Geosciences, 55099 Mainz, Germany \\ ${ }^{2}$ Carnegie Institution of Washington, Department of Terrestrial Magnetism, Washington, DC 20015, USA
}

Dunite, wehrlite and websterite xenoliths are rare members of the mantle xenolith suite within the Kimberley kimberlites of Southern Africa. They uniquely document a chronological sequence of metasomatism within the strongly depleted Kaapvaal cratonic upper mantle. This metasomtic sequence differs between xenoliths that represent lithologies located close to and xenoliths that come from areas located away from paths of melt infiltration.

Similar to the well known Kimberley peridotite xenoliths, dunite, wehrlite and websterite xenoliths are coarse grained and have a granular to porphyroclastic texture (Fig. 1). Websterite xenoliths are characterized by high modal orthopyroxene contents, while in dunites and wehrlites orthopyroxene is rare. The orthopyroxene is coarse-grained and replaces olivine. Additionally, all three xenolith types can contain clinopyroxene and garnet with an amoeboid texture, crystallizing along grain boundaries, replacing olivine and orthopyroxene. In some samples ilmenite and rutile crystallized together with clinopyroxene. Phlogopite and spinel occur subordinately.

Textural evidence and olivine major element compositions (e.g. low $\mathrm{CaO}$ contents of $<0.1 \mathrm{wt} . \%$ ) point towards dunitic to harzburgitic protolith compositions free of clinopyroxene. High $\mathrm{Mg} /(\mathrm{Mg}+\Sigma \mathrm{Fe})$ ratios in olivine and pyroxene $(0.88$ 0.93), high spinel $\mathrm{Cr} /(\mathrm{Cr}+\mathrm{Al})$ ratios of $0.64-0.84$ and mostly low whole-rock $\mathrm{SiO}_{2}$ (40-45 wt.\%), $\mathrm{CaO}$ $\left(<2\right.$ wt.\%) and $\mathrm{Al}_{2} \mathrm{O}_{3}$ contents $(<1 \mathrm{wt} . \%)$ indicate partial melting prior to metasomatism.

A mantle origin of dunite, wehrlite and websterite xenoliths is also evident from olivine $\delta^{18} \mathrm{O}$ values (4.9$5.6 \%$ ), that are similar to olivine in mantle peridotites (4.8-5.5\%o, Mattey et al., 1994). In contrast, $\delta^{18} \mathrm{O}$ values of clinopyroxene (4.8-5.8\%o) and garnet (4.6$5.5 \%$ ) are similar to slightly lower compared to mantle peridotites (5.3-5.9\%o and 5.0-5.9\%o, respectively). Orthopyroxene in the websterite xenoliths has $\delta^{18} \mathrm{O}$ values of 5.4-6.4\%o similar to slightly higher than mantle peridotites (5.4-6.1\%o). These indicate a separate origin of orthopyroxene, clinopyroxene and garnet from olivine.

Dunites and wehrlites have low $\mathrm{SiO}_{2}, \mathrm{Al}_{2} \mathrm{O}_{3}, \mathrm{CaO}$ and high $\mathrm{MgO}$ and $\mathrm{FeO}^{*}$ contents (e.g. Fig. 2). In contrast, websterites have higher $\mathrm{SiO}_{2}, \mathrm{Al}_{2} \mathrm{O}_{3}, \mathrm{CaO}$ and lower $\mathrm{MgO}$ and $\mathrm{FeO}^{*}$ compositions. Websterite xenoliths show trends of silica enrichment reflecting addition of orthopyroxene. In contrast, dunite and wehrlite xenoliths are enriched in $\mathrm{FeO}$ and $\mathrm{TiO}_{2}$ indicating a metasomatic overprint by basaltic melts, similar to mantle xenoliths from the Premier kimberlite (e.g. Hoal, 2003). These differences in metasomatism indicate that the dunite-wehrlite group and the websterite group have different spatial positions within
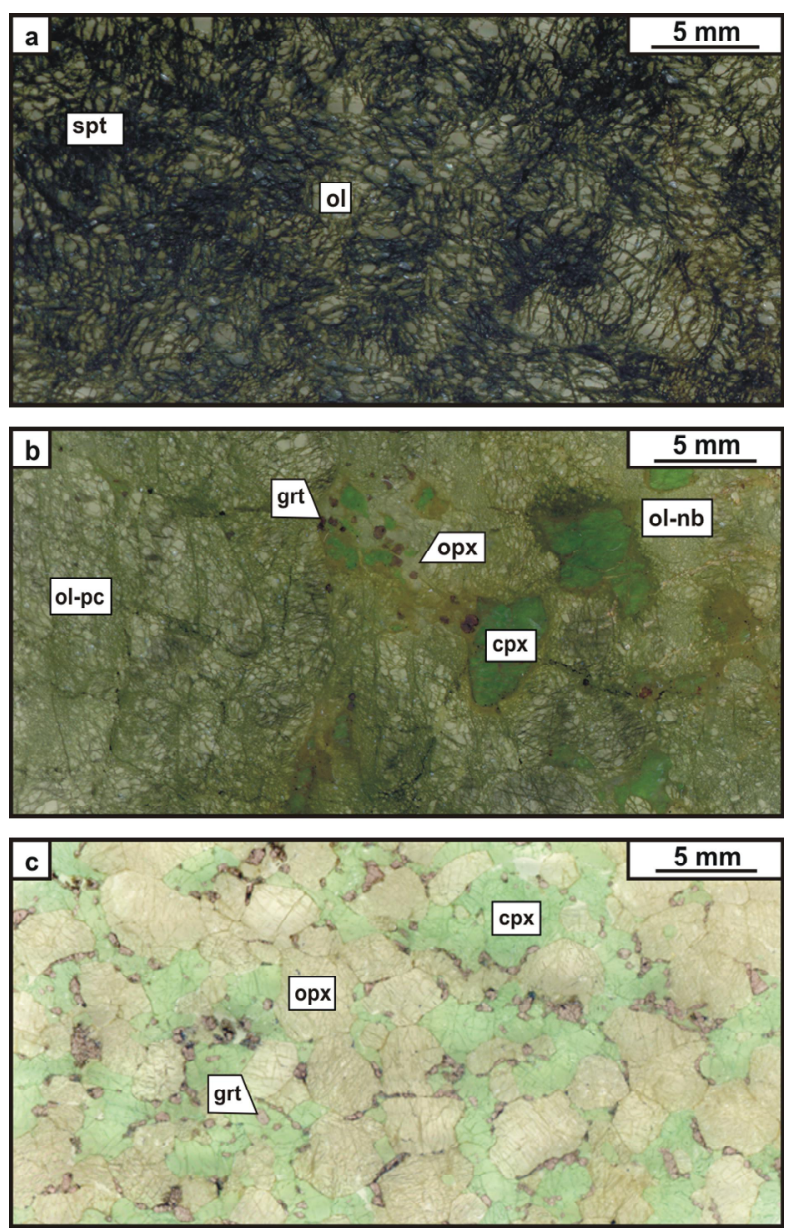

Fig. 1: Photomicrographs of dunite, wehrlite and websterite xenoliths ordered in the sequence of increasing metasomatism: a) dunite with coarse, slightly serpentinized (spt) olivine (ol), b) wehrlite with olivine porphyroclasts (olpc) and neoblasts (ol-nb) and clinopyroxene (cpx), garnet (grt) and orthopyroxene (opx) clusters, c) websterite with orthopyroxene consumed by clinopyroxene and necklace garnets crystallized along pyroxene margins. 
the Kaapvaal cratonic upper mantle.

Similarly, recalculated whole-rock trace element compositions reflect differences of dunites and wehrlites with websterites. The trace element budget is dominated by clinopyroxene, garnet and Ti-oxides, such as ilmenite and rutile (Fig. 3). Dunite xenoliths have the lowest whole-rock trace element contents compared to wehrlite and websterite xenoliths, with a similar shape to the wehrlitic trace element patterns. It is very uniform, has convex upward rare earth element (REE) patterns enriched in middle REE (MREE) relative to light REE (LREE) and heavy REE (HREE). The trace element concentrations vary in dunites and wehrlites due to dilution caused by different modal olivine contents. Garnet-bearing wehrlites are slightly enriched in HREE. The occurrence of ilmenite and rutile in dunites and wehrlites causes positive high field strength element peaks. Different to dunite and wehrlite xenoliths, websterite xenoliths have concave REE patterns, mostly enriched in LREE and HREE due to a higher proportion of clinopyroxene and garnet. Additionally, they have negative HFSE anomalies compared to wehrlite and dunite xenoliths.

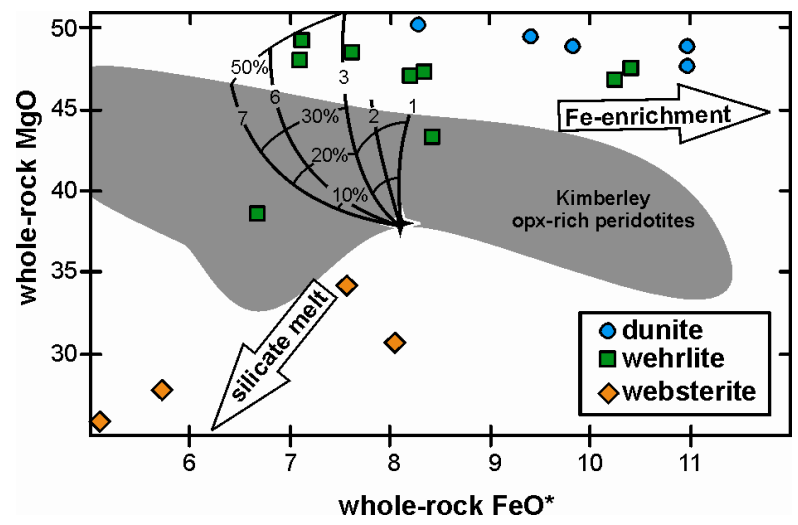

Fig. 2: Recalculated whole-rock $\mathrm{MgO}$ versus $\mathrm{FeO}^{*}$ composition [wt.\%] of dunite, wehrlite and websterite xenoliths, compared to Kaapvaal orthopyroxene-rich peridotites (e.g. Boyd \& Mertzman, 1987, Simon et al., 2007). Arrows indicate trends of enrichment. Petrogenetic grids starting at primitive mantle composition (black star; McDonough \& Sun, 1995) indicate trends of residual mantle compositions at increasing melt depletion (vertical lines in $\%$ ) and different pressures (horizontal lines in GPa; redrawn after Walter, 2003).

Clinopyroxene and garnet in dunite, wehrlite and websterite xenoliths have two distinct trace element patterns: one wehrlitic and one websteritic. The wehrlitic pattern is characterized by small negative Ti and positive $\mathrm{Hf}$ anomalies, and a slight enrichment in clinopyroxene MREE that is reflected in low chondrite normalized $(\mathrm{La} / \mathrm{Yb})_{\mathrm{CN}}$ ratios of 5-9. In contrast, websteritic clinopyroxene and garnet have trace element patterns with strong negative $\mathrm{Ti}$ and smaller Zr-Hf anomalies and a steep decrease from LREE to HREE with $(\mathrm{La} / \mathrm{Yb})_{\mathrm{CN}}=22-680$ in clinopyroxene. In comparison to equilibrium mineral/mineral trace element partition coefficients (Glaser et al., 1999, Green et al., 2000), the calculated garnet-clinopyroxene

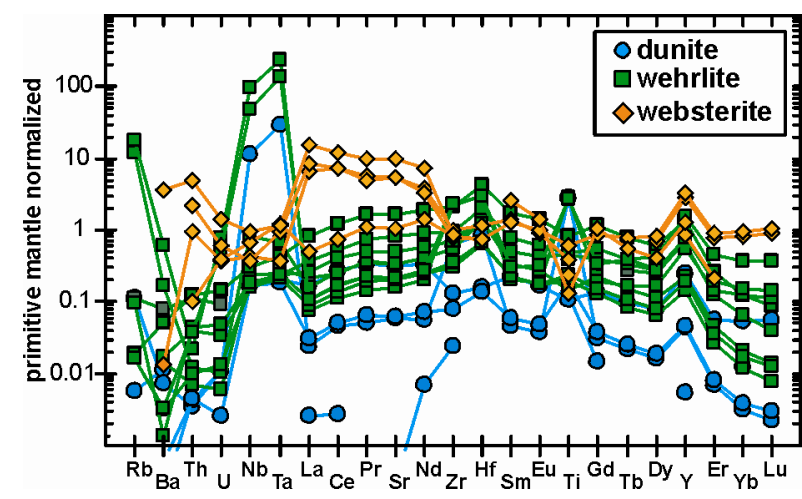

Fig. 3: Recalculated whole-rock trace element compositions of dunite, wehrlite and websterite xenoliths normalized to the primitive mantle (McDonough \& Sun, 1995).

partition coefficients in dunites, wehrlites and websterites reflect equilibrium (Fig. 4a), indicating a similar petrogenetic origin of clinopyroxene and garnet. Calculated clinopyroxene and garnet equilibrium melt compositions of wehrlite xenoliths have similarities with primitive basaltic melts or melts derived by partial melting of eclogite. In contrast, clinopyroxene-orthopyroxene partition coefficients (Fig. 3b) and garnet-orthopyroxene partition coefficients (not shown) are not in equilibrium in dunite, wehrlite and websterite xenoliths, reflecting a separate origin of orthopyroxene.

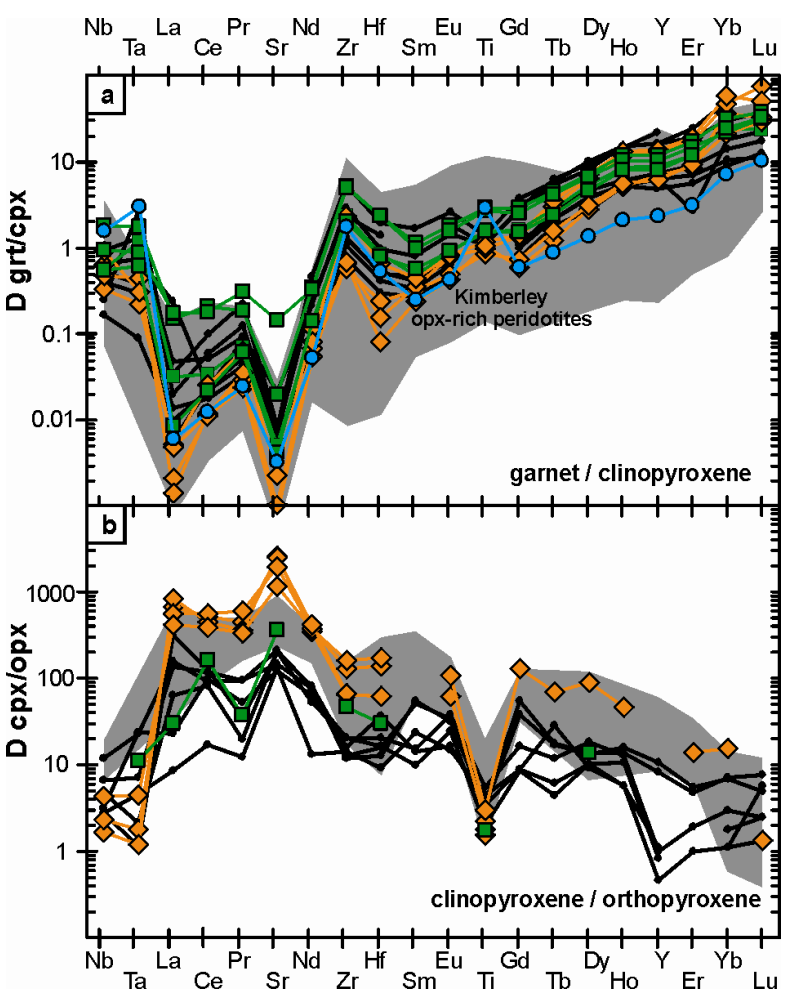

Fig. 4: Calculated (a) garnet-clinopyroxene (D grt/cpx) and (b) clinopyroxene-orthopyroxene partition coefficients (D cpx/opx) in dunite, wehrlite and websterite xenoliths compared to Kimberley orthopyroxene-rich peridotites (grey field; Grégoire et al., 2003, van Achterbergh, 2004, Simon et al., 2007) and equilibrium partition coefficients (black lines; Glaser et al., 1999, Green et al., 2000). 
Whole-rock dunite, wehrlite and websterites have low Re concentrations of mostly $<0.3 \mathrm{ppb}$, moderate to low Os contents of 0.03-6.6 ppb in dunites and wehrlites and mostly $<1 \mathrm{ppb}$ in websterites. Olivine mineral separates of dunite and wehrlite xenoliths have a narrower range and lower $\operatorname{Re}(<0.1 \mathrm{ppb})$ and $\mathrm{Os}$ concentrations $(<1 \mathrm{ppb})$ than whole-rocks, indicating significant sequestration of these elements in interstitial phases. The whole-rock ${ }^{187} \mathrm{Os} /{ }^{188} \mathrm{Os}$ ratio of wehrlite, most dunites and websterites calculated back to the time of the kimberlite eruption at $86 \mathrm{Ma}$ is unradiogenic with $\gamma \mathrm{Os}$ from -18 to -8 . Most dunites, wehrlites and websterites have low ${ }^{187} \mathrm{Re} /{ }^{188} \mathrm{Os}$ ratios of 0.02-0.5. The majority of the samples analysed give Archaean Re-depletion model ages of $2.9 \pm 0.3 \mathrm{Ga}$, similar to Kaapvaal mantle peridotites $(2.5 \pm 0.6 \mathrm{Ga}$; e.g. Pearson et al., 1995, 2004, Simon et al., 2007), showing clearly that melt depletion is the fundamental chemical process that determined the Re-Os systematics of these samples. Most wehrlite xenoliths, one websterite and most Kaapvaal peridotite xenoliths show a trend of increasing ${ }^{187} \mathrm{Os} /{ }^{188} \mathrm{Os}$ (86 Ma) at increasing whole-rock $\mathrm{SiO}_{2}$ (Fig. 5), $\mathrm{Al}_{2} \mathrm{O}_{3}$ and decreasing $\mathrm{MgO}$ content, while most websterite xenoliths have constant low ${ }^{187} \mathrm{Os} /{ }^{188} \mathrm{Os}(86 \mathrm{Ma})$. This may indicate an Archaean age for the silica-enrichment in websterite xenoliths, while wehrlites and one websterite are influenced by young metasomatic overprint. Three wehrlite xenoliths provide two-point olivine-whole-rock tie lines with slopes corresponding to ages of $186 \mathrm{Ma}, 295 \mathrm{Ma}$ and $302 \mathrm{Ma}$. The similarity of the ages may suggest that the metasomatic overprint of the wehrlites occurred in the Mesozoic (probably Karoo). In contrast, dunite has a large variability in Os isotope compositions at constant whole-rock major element compositions (Fig. 5). Due to the overall low Os contents in dunite it is extremely susceptible to kimberlite infiltration.

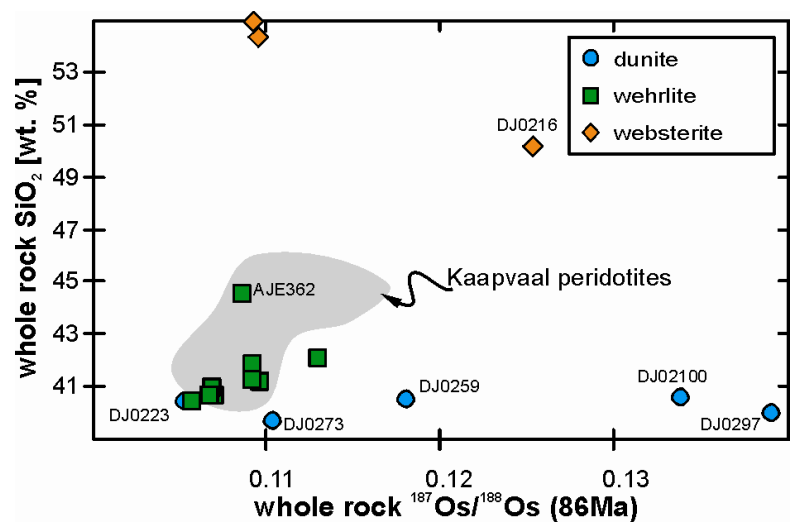

Fig. 5: Whole-rock Os concentration [ppb] versus $187 \mathrm{Os} / 188 \mathrm{Os}(\mathrm{t})$ at time of kimberlite eruption (86 Ma), compared to Kaapvaal peridotites (Simon et al., 2007).

According to Re-Os systematics melt depletion occurred prior to $2.9 \mathrm{Ga}$. The sequence of metasomatism documented by the samples includes orthopyroxene-enrichment and clinopyroxene and garnet crystallization. The first metasomatic overprint is related to subduction of oceanic crust 2.9-2.7 Ga ago. Partial melting of eclogite produces silica-rich melt (>60 wt.\% SiO2) that reacts with surrounding mantle, changing olivine into orthopyroxene. Later (Mesozoic), percolating basaltic melts induce crystallization of clinopyroxene and garnet and enrich the mantle in $\mathrm{CaO}, \mathrm{Al}_{2} \mathrm{O}_{3}, \mathrm{FeO}$ and high field strength elements. Websterites have experienced both orthopyroxene-enrichment and clinopyroxene plus garnet crystallization probably representing mantle lithologies located close to paths of melt infiltration. In contrast, dunites and wehrlites are located further away from paths of melt infiltration since they have only experienced the clinopyroxene and garnet crystallization. This indicates spatial differences in the type and severity of metasomatism within the upper mantle.

\section{References}

Boyd, F. R.Mertzman, S. A., 1987. Composition and structure of the Kaapvaal lithosphere, southern Africa. In: Mysen, B. O. (ed.) Magmatic processes: physicochemical principles. The Geochemical Society, 13-24.

Glaser, S. M., Foley, S. F.Günther, D., 1999. Trace element compositions of minerals in garnet and spinel peridotite xenoliths from the Vitim volcanic field, Transbaikalia, eastern Siberia. Lithos 48, 263-285.

Green, T. H., Blundy, J. D., Adam, J.Yaxley, G. M., 2000. SIMS determination of trace element partition coefficients between garnet, clinopyroxene and hydrous basaltic liquids at $2-7.5 \mathrm{GPa}$ and $1080-1200^{\circ} \mathrm{C}$. Lithos 53, 165-187.

Grégoire, M., Bell, D. R.Le Roex, A. P., 2003. Garnet lherzolites from the Kaapvaal Craton (South Africa): Trace element evidence for a metasomatic history. Journal of Petrology 44 (4), 629-657.

Hoal, K. O., 2003. Samples of Proterozoic iron-enriched mantle from the Premier kimberlite. Lithos 71, 259272.

Mattey, D., Lowry, D.Macpherson, C., 1994. Oxygen isotope composition of mantle peridotite. Earth and Planetary Science Letters 128, 231-241.

McDonough, W. F.Sun, S.-S., 1995. The composition of the Earth. Chemical Geology 120, 223-253.

Pearson, D. G., Carlson, R. W., Shirey, S. B., Boyd, F. R.Nixon, P. H., 1995. Stabilisation of Archaean lithospheric mantle: A Re-Os isotope study of peridotite xenoliths from the Kaapvaal craton. Earth and Planetary Science Letters 134, 341-357.

Pearson, D. G., Irvine, G. J., Ionov, D. A., Boyd, F. R.Dreibus, G. E., 2004. Re-Os isotope systematics and platinum group element fractionation during mantle melt extraction: a study of massif and xenolith peridotite suites. Chemical Geology 208, 29-59.

Simon, N. S. C., Carlson, R. W., Pearson, D. G.Davies, G. R., 2007. The origin and evolution of the Kaapvaal cratonic lithospheric mantle. Journal of Petrology 48 (3), 589-625.

van Achterbergh, E., 2004. Geochemical fingerprints of mantle metasomatism. Department of Earth and Planetary Sciences. Sydney: Macquarie University, 223.

Walter, M. J., 2003. Melt extraction and compositional variability in mantle lithosphere. In: Carlson, R. W. (ed.) Treatise on Geochemistry: The mantle and core. Elsevier, 363-394. 